\title{
The deep waters of land reform: land, water and conservation area claims in Limpopo Province, Olifants Basin, South Africa
}

\author{
Janwillem Liebrand ${ }^{\mathrm{a} *}$, Margreet Z. Zwarteveen ${ }^{\mathrm{a}}$, Philippus Wester \\ and Barbara van Koppen ${ }^{\mathrm{b}}$ \\ ${ }^{a}$ Irrigation and Water Engineering Group, Wageningen University, the Netherlands; ${ }^{b}$ International \\ Water Management Institute, Southern Africa, Pretoria, South Africa
}

(Received 6 June 2012; final version received 14 October 2012)

\begin{abstract}
Through investigating the reactions of commercial farmers to land and water reforms in the Trichardtsdal-Ofcolaco area, Limpopo Province, Olifants Basin, South Africa, from 1997 to 2006, it is shown that water claims are key to land redistribution processes, and that commercial farmers make strategic use of arguments for nature conservation and ecological stewardship to defend their claims to water. Given these observations, caution is warranted with respect to the implementation of land and water reforms as separate policy packages; it may be more effective to design water and conservation policies as an integral part of land reform programmes.
\end{abstract}

Keywords: water reform; land reform; nature conservation; water rights; Olifants Basin; South Africa

\section{Introduction}

The post-apartheid South African government of the 1990s formulated land and water reform policies to redress historic race and gender inequities, as part of a broader commitment to achieve a more equitable and fair distribution of the country's wealth. In 1994, the Reconstruction and Development Programme of the African National Congress (ANC) proclaimed land reform the "central and driving force of a programme of rural development" (ANC 1994, Hall 2010). Water reforms were treated separately, largely through the National Water Act of 1998 (RSA 1998). Though widely hailed as comprehensive and politically progressive (Van Koppen and Jha 2005), and in spite of its explicit focus on equity, the National Water Act did little to bring about a more just allocation and use of water. Indeed, access to both land and water in South Africa continues to be concentrated in the hands of a privileged few, and highly skewed along racial lines (Waalewijn et al. 2005, Merrey et al. 2009, Goldin 2010, Hall 2010, Herrfahrdt-Pähle 2010, Brown 2011, Kemerink et al. 2011).

Some attribute this lack of success to the strong neo-liberal flavour of new policies and laws (Chikozho 2008). Most analyses identify weaknesses in implementation and enforcement as the major causes for failure (World Bank 2003, Anderson et al. 2008). This article suggests that the dynamics and outcomes of land and water reforms also

*Corresponding author. Email: Janwillem.Liebrand@wur.nl 
need to be understood as embedded in historically evolved and locally specific patterns of use that form an important part of and co-constitute relations of power (cf. Goldin 2010). The analysis builds on a characterization of the present land and water situation in South Africa as a legally pluralist one, and uses this to explain that there are many spaces and opportunities for people with vested interests to bend the new rules to their favour (see Van Koppen and Jha 2005, Kemerink et al. 2011). To understand how this occurs, this study investigated how White commercial farmers perceived reforms and tried to deal with the consequences. ${ }^{1}$ It documents these farmers' reactions to state interventions from 1997 to 2006 in the commercial farming area of Trichardtsdal-Ofcolaco, Limpopo Province, Olifants Basin (Liebrand 2009).

This analysis is used to make two points. The first and more general point is that actual water uses are only very partially shaped (or directed) by formal water laws and policies. Actual water use and distribution come about through more or less legitimate forms of appropriation and access, whereby opportunities are importantly shaped by historically evolved patterns of use that are embedded in (and constituted by) prevailing social relations of power. The second and more specific point follows on from this, and is that water and land reforms, and the nature conservation goals related to those policies, are intimately interlinked. This may seem self-evident, but few studies acknowledge the connections between land, nature conservation and water, even though some note that water resources (and grazing lands) are often at the root of conflicts and disputes over land (e.g. Kirsten et al. 2000, Anseeuw and Alden 2010). Negotiations about land redistribution and the conservation status of land are often (just or also) about the use of water, and vice versa. Hence, access and ownership patterns of the one resource cannot be understood, or altered, without also understanding or altering the other.

The next section presents the theoretical points of departure. The article continues with a brief sketch of the methodology, after which it moves on to the historical and sociopolitical background of the area. Four events are then focused on which illustrate the strategies of White commercial farmers to secure their (continued) access to land and water resources.

\section{Understanding land, water and conservation area claims in contexts of scarcity}

To understand complex and dynamic land and water reform negotiations, this study makes use of insights from legal-anthropological scholarship on property and access (von BendaBeckmann and Spiertz 1996, Ribot and Peluso 2003, von Benda-Beckmann et al. 2006). This body of work is different from most writings on land and water reforms in that it is less concerned with what should happen and more with trying to describe and understand what is actually occurring. The interest is in how people experience law in the context of their own social environment and in how they use it as a resource in their day-to-day aspirations and struggles (see Roth et al. 2005). Through studying real-life manifestations of law in specific settings, legal-anthropological studies have shown that the linkages between property, power and social (in)equalities are complex and multi-stranded, and mediated by locally and historically specific and dynamic social configurations of claims, responsibilities and rights (see von Benda-Beckmann et al. 2006).

For grasping this, the term 'embeddedness', a metaphor introduced by Polanyi (1944), is one that is often invoked. It expresses the idea that institutions like property are basically social institutions, reflecting a complex alchemy of politics, culture, economics and ideology (Hann 1998, McCay and Jentoft 1998, Krippner 2001). Property and access form part, and are often expressions of, wider social relationships, including relations of class, status, 
ethnicity and gender. They embody the norms and values that are regarded as legitimate in a community, often also reflecting power differences and even past or ongoing violence that has become 'normalized' in structures of authority and discourses (see Peluso and Lund 2011).

Perhaps even more than land, the access and use of water tends to be deeply contested and political, and is therefore intimately linked to issues of power and authority (Zwarteveen 1997, Boelens and Zwarteveen 2005, Sikor and Lund 2009). Understanding the actual patterns of water distribution requires looking at how people gain and maintain the ability to access water, instead of just looking at their rights to it (see Ribot and Peluso 2003). Water security consists of the belief that one holds a particular privilege, as against others, in the use, management or political-institutional control of water at a particular time. This security can be based on a variety of legal grounds (e.g. state law or customary notions of fairness, principles and rights) but also on other processes and mechanisms through which access can be created, maintained and expanded (see Ribot and Peluso 2003, Meinzen-Dick and Nkonya 2007, Peluso and Lund 2011).

This theoretical approach is used here to analyze how vested powers, in this case White commercial farmers, safeguard their water security (against Black claimants' water insecurity) by making use of new statutory land and water laws. The article scrutinizes how the disconnect between land and water policies, both designed to redress inequities, further allowed this to happen, particularly in relation to nature conservation goals. The legalpluralist perspective on property and access also helps understand how commercial farmers in South Africa make strategic use of nature conservation and ecological stewardship arguments to justify their claims to land and water (cf. Fortmann 1995).

\section{Methodology and background of interviewees}

The first author of this article conducted field research from April to August 2006. He was accommodated and hosted by an Afrikaner farm household (Liebrand 2009), which provided an inside understanding of White farmers' perspectives. The established relations of trust with the White farmers' community also helped in the gaining of access to the archives of the local farmers' associations of Trichardtsdal-Ofcolaco and Leydsdorp, and of the Selati River Irrigation Board. Alongside ethnographic observations and a review of the files, the research consisted of interviews with 24 commercial farmers. All interviewees were male, and 22 of them had an Afrikaner or English background, while two were Black commercial farmers. ${ }^{2}$ Research focused on farmers who identified themselves as ploeg ' $n$ planters (plough and crop farmers). These are White farm households that seek to maximize profits in commercial crop production by using intensive methods of irrigation (e.g. canal, pump, pivot, drip and sprinkler), depend on high volumes of water for agriculture, and employ a few hundred (Black) workers. ${ }^{3}$

The properties of commercial farmers ranged from 81 to 910 ha, with an average of 485 ha. Much land on these farms lay fallow (bush land) or was under extensive cultivation (orchards). Areas under intensive production, i.e. under irrigation, ranged from 15 to 500 ha, with an average of 140 ha. The subtropical temperatures are ideal for fruit and vegetable production, as well as for cotton and fodder crops, but rainfall is erratic and follows a clear wet (December to April) and dry (May to October) seasonal pattern. Two data-sets of commercial farmers (1963-2005 and 1993-2005) revealed that the average rainfall was approximately $675 \mathrm{~mm}$ per year, but that the $80 \%$ probability was markedly lower: $275 \mathrm{~mm}$ per year. Under these conditions, irrigation is a prerequisite for commercial farming, especially in the dry season. Groundwater was available throughout the area via 
boreholes, but underground supplies fluctuated markedly and, according to the farmers, depended on rainfall and degrees of utilization.

The key role of the former chairman of the Farmers' Association of TrichardtsdalOfcolaco (FATO) soon became clear during the research. His political insights, networks and dealings crucially determined the nature and direction of the negotiations of the farmers with outside government agencies and others, and helped them to secure their water. $\mathrm{He}$ was one of the owners of the farms that were transferred to the claimants in 2005, as part of the Restitution of Land Rights Act (1994) (RSA 1994). He also was portfolio holder for land reforms in AgriSA, the national agricultural trade organization of commercial farmers in South Africa, ${ }^{4}$ and was engaged in high-level national debates on land reform policies with the then regional land claims commissioner of Limpopo Province.

\section{Historical and socio-political background of the research area}

The research team studied the White settlements of Trichardtsdal, Ofcolaco and Leydsdorp in Limpopo province, situated about $60 \mathrm{~km}$ south-east of Tzaneen, the largest nearby town. This area covers some 25,000 ha and largely falls in the Upper Selati catchment of the Olifants River basin. It is situated in the well-watered foothills of the Drakensberg Mountains (see Figure 1). In August 2006, at the time of the study, about 20 out of 50 commercial "plough and planter" farm households had left the area, and some 30 farm households, excluding game farmers, were still active. Densely populated Black settlements of the former homelands of Gazankulu and Lebowa border the area in the north and south, respectively.

The forested slopes of the Drakensberg Mountains are the source of most of the water needed for irrigating the farms; the Macheke Springs and two rivers - the Makhutsi and the Selati - feed the irrigation canals, as well as the underground aquifers used for groundwater extraction. These water sources are located in what is designated as the Lekgalameetse

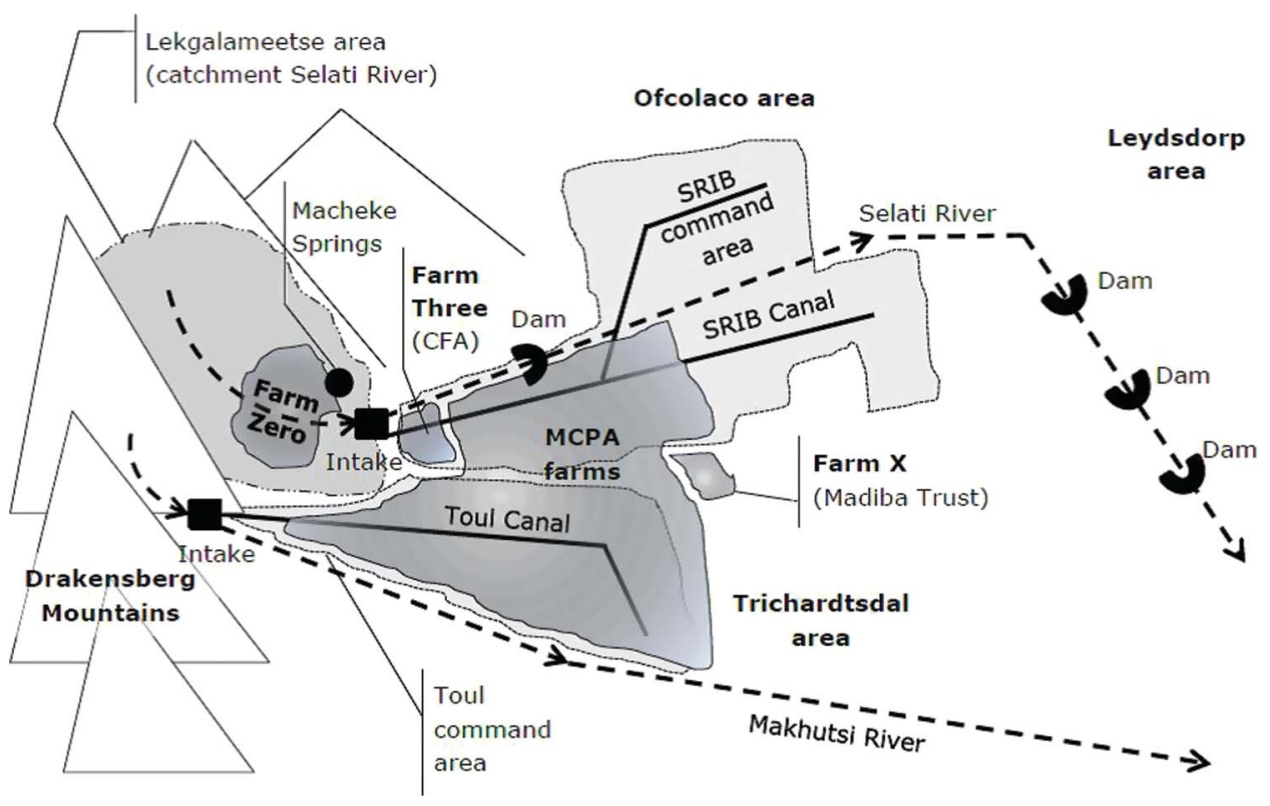

Figure 1. Layout of the research area. 
Nature Reserve (LNR). It is because of these important water sources that this upper catchment features prominently in the area's development. As the discussion that follows shows, struggles to secure control of this upper catchment have influenced land reform and land claims in the area. An historical overview of land and water uses and users in the area clearly shows that access to water has always played a prominent role in the dynamics of the region's socio-political history.

\section{Until the 1990s}

The water-rich upper catchment area, the LNR, was inhabited long before it was first mentioned in colonial records. This is evident from graves and other important ritual sites. The people who lived in the area over a hundred years ago were the Tebula. The name of the river Selati comes from Shalati, who was their female chief. The availability of water also attracted the first White occupants to this place, around the turn of the twentieth century. They settled at the top of the escarpment of the Drakensberg Mountains (Chapman 2006). In the 1920s, British officers established the Officers Colonial Land Company (Ofcolaco) for farming and began to irrigate the land..$^{5}$ Black communities' extensive grazing activities were gradually displaced by the White settlers' more intensive farming operations. The company was soon abolished, but shareholders continued farming individually, and called their farmers' association Ofcolaco.

The apartheid government actively promoted the appropriation and use of land and water by White farmers, not just by allowing them to use the land, but also by subsidizing the construction of irrigation infrastructure (cf. Turton et al. 2004, Goldin 2010). Around 1940, a first White irrigation furrow diverting water from the Makhutsi River the Toul Canal (see Figure 1) - was constructed for the properties Toul and Balloon. It is likely that the government also supported the construction of a second canal in 1972, this time to divert water from the Selati River. This canal, with a capacity of $280 \mathrm{~L} / \mathrm{s}$, was built for 12 White properties to irrigate a planned area of 998 hectares (see Figure 1). ${ }^{6}$ The Selati River Irrigation Board (SRIB), responsible for operating and maintaining the canal, obtained formal status in 1964 (through a proclamation in the Government Gazette 1964). Unlike the Toul Irrigation Board, the SRIB was still in place in 2006.

In the 1970s, the Trichardtsdal-Ofcolaco area was subject to land consolidation policies of the apartheid administration aimed at expanding the former homeland of Lebowa. For this purpose, the government purchased the properties of White commercial farmers and imposed restrictions on the use of fragile areas such as forests. It was in this process that the upper catchment of the Selati River, the Lekgalameetse area, was first put on the map as the Legkalameetse Nature Reserve (LNR) within Lebowa. However, to their dismay, the tribal authorities of Lebowa were not given full authority over the LNR area. Through assigning the area conservation status, grazing and water use practices of Black communities were curtailed, and the continued use of river flows downstream by White farmers was safeguarded. ${ }^{7}$ Eventually, land consolidations stalled in 1987, and in 1992 the government sold most of that land in the Trichardtdal-Ofcolaco area to White and some Black commercial farmers. Most farmers said that they had obtained their properties from 1992 onwards. The LNR area remained in the hands of the government, and maintained a conservation status. ${ }^{8}$ As the discussion that follows shows, gaining control over the LNR was seen by the White commercial farmers as key to securing access to water, which is why a proposed land transfer in the LNR from government to claimants was a source of much contestation and struggle. 


\section{Post-apartheid}

From 1997 onwards, the area has been subject to various state interventions related to land and water reforms. From 1997 to 1999, various White farms were transferred to large groups of beneficiaries through a settlement/land acquisition grant (SLAG) of ZAR15,000 per household (see Hall 2010 for background on the SLAG). ${ }^{9}$ Two land transfers that occurred under this scheme were the redistribution of a farm property called here Farm Three (200 ha) to the Calais Farmers' Association (CFA) (390 beneficiary households) and the transfer of Farm X (163 ha) to the Madiba Trust (187 beneficiary households, also see Figure 1). ${ }^{10}$ A second land redistribution scheme, the Restitution of Land Rights Act (1994), allowed the transfer of 13 properties (5016 ha) in 2005 to beneficiaries of the Sekoro communities (see Dippenaar et al. 2005 for background on land claims of the Sekoro communities). This happened after an intensive five-year negotiation process between Black claimants, White farmers and the government. The 13 farms were distributed to the Makhutsi Communal Property Association (MCPA), which was to function under a strategic partnership scheme (between one or more investors, often commercial farmers, and the beneficiary claimant-farmers) with the objective of developing commercial farming activities. ${ }^{11}$ In August 2006, some of the land was being used for grazing, but most lay idle. The strategic partnership scheme, under the leadership of two White farm managers who had entered into a "partnership" with the MCPA as "strategic partners", was about to start farming operations. Similar situations were visible in the two SLAG farms distributed earlier; some land was being used for grazing, most lay idle, and some small agricultural activities took place at the farm of the Madiba Trust.

Water reforms were conducted parallel to, but separate from, land reforms. Water reforms in the area entailed the registration of water uses and the establishment of water users' associations (WUAs). Compulsory licensing of water use, and any possible subsequent redistribution of water resources, was not pursued by the government. Most water use by the commercial farmers in 2006 fell under the definition of "existing lawful use", that is, water use that lawfully took place in the period of two years before the commencement of the National Water Act of 1998, because these same farmers had been using similar amounts of water before 1996 (DWAF 2005). ${ }^{12}$

The rest of this article zooms in on four particular events that took place between 1997 and 2006 and were related to government-led initiatives to reform land and water use. In describing these events, the article focuses on the strategies of White commercial farmers to secure their (continued) access to land and water resources: (1) the registration of water uses around 2000; (2) the "transformation" of the SRIB into a WUA starting in 1999; (3) the redistribution of farms under SLAG schemes in 1997-1999; and (4) the transfer of farms for the restitution of land rights in 2000-2005.

\section{Registration of water uses around 2000}

Initially, commercial farmers were eager to cooperate with the water use registration process. ${ }^{13}$ This was so because they perceived it as providing them with evidence of their rights to access water, despite the water use registration certificates' explicit statement that new water use authorizations would be handled through a separate process of licensing (certificates were dated 20 May 2002). ${ }^{14}$ The farmers' enthusiasm started waning when the Department of Water Affairs and Forestry (DWAF) requested that they pay "water resource management" charges. ${ }^{15}$ The example of the SRIB farmers illustrates this. In September 2006, the SRIB still consisted of five White farmers whose lands were located in the middle and tail end (lowest portion) of the system. Farmers belonging to the SRIB had their water 
uses registered collectively. When the DWAF urged the SRIB to pay its outstanding water charges, the SRIB farmers joined other farmers in protests that the charges were too high. The following quote from a letter of the SRIB (dated 19 August 2004) to the DWAF office in Nelspruit reveals that the White farmers felt that they were charged for the maximum capacity of water use, while they rarely had an opportunity to use that amount of water:

The water levy account submitted to the Irrigation Board firstly has no bearing on the water usage from the canal and secondly is largely un-recoupable... . The canal has a "theoretical" capacity of $0,227 \mathrm{~m}^{3} / \mathrm{s}$. The average flow measured at the top flume between 1989 and 1995 was $0,068 \mathrm{~m}^{3} / \mathrm{s}$ or $30 \%$ of optimal supply. The highest reading during that 7 years period was in March 1991 of $0,159 \mathrm{~m}^{3} / \mathrm{s}(70 \%)$ and the lowest in December 1993 of $0,009 \mathrm{~m}^{3} / \mathrm{s}$ (4\%). Conversely, during the years of plenty between 1966 and 2002 the average flow was $0,201 \mathrm{~m}^{3} / \mathrm{s}(90 \%)$.

Like other farmers, the SRIB farmers therefore argued for a re-registration of water use. They proposed doing this in the name of individual users, rather than as a collective. In response, the DWAF (half a year later, in a letter dated 19 January 2005) asked the SRIB for information on individual water uses within the system.

The SRIB's reaction to this request, noted in the minutes of 20 September 2005, was to fabricate an irrigation schedule that quantified water shares and related levies of the board (see Table 1). Expressing water uses in volumes rather than in shares of water marked a notable shift in the SRIB's approach to water allocation. In the 1970s, the newly built Selati Canal had affected riparian water shares of farmers whose fields were located downstream from the intake. At that time, it was agreed that adjacent properties could extract water either from the river or from the canal, with allocation being based on proportional shares. Hence, the most upstream two properties (Farms One and Two) under the SRIB's jurisdiction had never been served by the canal, but nevertheless had rights ("votes") to extract water from the Selati River and the Macheke Springs.

Table 1. Revised irrigation schedule of the SRIB. (LNR: Lekgalameetse Nature Reserve. CFA: Calais Farmers' Association. MCPA: Makhutsi Communal Property Association.).

\begin{tabular}{|c|c|c|c|c|c|c|c|}
\hline \multirow[b]{2}{*}{$\begin{array}{l}\text { Name of } \\
\text { property }\end{array}$} & \multirow[b]{2}{*}{ Votes } & \multirow[b]{2}{*}{ Owner/leaser } & \multirow[b]{2}{*}{$\begin{array}{l}\text { Irrigated } \\
\text { area (ha) }\end{array}$} & \multirow{2}{*}{$\begin{array}{c}\text { Source (Selati } \\
\text { River, Macheke } \\
\text { Springs, or Selati } \\
\text { Canal) }\end{array}$} & \multicolumn{2}{|c|}{ Theoretical } & \multirow{2}{*}{$\begin{array}{l}\text { Rates, } \\
\text { Oct. 2005 } \\
\text { (ZAR) }\end{array}$} \\
\hline & & & & & $\begin{array}{l}\text { Share of } \\
8 \mathrm{~m}^{3} / \mathrm{s}\end{array}$ & $\mathrm{L} / \mathrm{s}$ & \\
\hline Farm Zero & 0 & State (LNR) & 43 & River & - & - & \\
\hline Farm One & 1 & State & 86 & River/springs $50 \%$ & - & - & 429.00 \\
\hline Farm Two & 1 & $\begin{array}{l}\text { State (Black } \\
\text { farmers) }\end{array}$ & 86 & Springs $50 \%$ & - & - & 429.00 \\
\hline Farm Three & 1 & CFA & 86 & Canal & 0.87 & 25 & 429.00 \\
\hline Farm Four & 1 & MCPA & 86 & Canal & 0.87 & 25 & 429.00 \\
\hline Farm Five & 1 & MCPA & 86 & Canal & 0.87 & 25 & 429.00 \\
\hline Farm Six & 1 & MCPA & 111 & Canal & 1.14 & 32 & 558.00 \\
\hline Farm Seven & 1 & White farmer & 86 & Canal & 0.87 & 25 & 429.00 \\
\hline Farm Eight & 1 & White farmer & 64 & Canal & 0.66 & 19 & 322.00 \\
\hline Farm Nine & 1 & White farmer & 64 & Canal & 0.66 & 19 & 322.00 \\
\hline Farm Ten & 1 & White farmer & 67 & Canal & 0.66 & 19 & 336.00 \\
\hline $\begin{array}{l}\text { Farm } \\
\text { Eleven }\end{array}$ & 2 & White farmer & 134 & Canal & 1.40 & 39 & 672.00 \\
\hline Total units: & 12 & & 998 & & 8.00 & 228 & \\
\hline
\end{tabular}

Source: Selati River Irrigation Board minutes, 20 September 2005. Owner/leaser has been made anonymous. 
The new schedule instead divided the available water into 12 volumetric shares (or "units"). The quantity of one share was calculated on the basis of the estimated irrigated land size and the design capacity of the canal $(228 \mathrm{~L} / \mathrm{s})$. An important aim of this exercise was for the SRIB farmers to (re)gain control over "their" water, and in particular over the upper catchment of the Selati River and the Macheke Springs. They therefore included the first two properties in the schedule as a conservation area, but conveniently did not quantify how many shares these properties were entitled to. The farms were nevertheless charged for (potential) water use. The schedule thus reveals a three-fold strategy to secure water use. First, the farms were claimed by the SRIB as "conservation areas". Second, the farms were not allocated water shares, and third, the SRIB envisioned restricting the potential, but in fact existing, water use through charging for it. Likewise, the SRIB schedule also included Farm Zero, which is located strategically in the LNR but was never fully part of the area under the SRIB's jurisdiction, as the first property, though without any votes or rights to water. Hence, rather than documenting and registering actual water uses, the SRIB farmers constructed a hypothetical schedule to express how they would like water to be allocated, thus strengthening their claims to the upstream catchment and water sources.

\section{From irrigation board to WUA: 1999 and after}

In 1999, the DWAF initiated a process for turning the SRIB into a WUA by sending stepby-step instructions (dated 3 July 1999) on how to develop a new constitution in a stipulated period of six months (DWAF 1999). As with the registration of water use, the SRIB farmers set out to use this "re-organization" of the board to strengthen their control over water by attempting to include the upper catchment of the Selati River in the area commanded by the WUA. As shown in the previous section, the SRIB had never fully controlled the upper catchment of the Selati River. In the 1980s, this section of land had been partially designated as a nature reserve, but had formally remained under control of the government. As a result, and to the farmers' frustration, the SRIB had been unable to stop the operations of an old (irrigated) avocado farm administered by a (public) development cooperation. Nor had the SRIB succeeded in curbing the grazing of cattle that occurred under the authority of tribal leaders. With the transfer of Farm Three to the CFA in 1997, the situation for the SRIB in terms of water had further deteriorated, as people of the Calais community located at the head-end of the system had started using canal water for domestic purposes.

The White SRIB farmers saw the establishment of a WUA as an opportunity to gain control over the upper catchment, and thus to safeguard their future access to water. ${ }^{16}$ They used the DWAF's own advice that the boundaries of the area controlled by the WUA should be based on catchment management and conservation rationales. In a three-page business plan produced in early 2000, the SRIB farmers clearly staked their claim by proposing "Upper Selati Water User Association" as the name for the new WUA. Soon after, the SRIB secretary drew up a nine-page constitution for the WUA, following the DWAF guidelines. The secretary used this new constitution to strategically determine new boundaries for the area under the WUA's jurisdiction, making sure that it included the upper catchment of the Selati River and the Macheke Springs in the LNR. ${ }^{17}$

The DWAF instructions explicitly mentioned that the new WUA should commit itself to "appropriate racial and gender representation". The draft constitution complied with this by stating that anyone using water from the source, waterways or canal of the Selati River could become a member of the WUA. Also, the business plan explicitly mentioned that the new WUA would base its decisions on the general assembly of its members. In actual fact, the process was heavily dominated and steered by the five White farmers still active 
in the area. According to them, it was difficult to meaningfully involve other (Black) users in the drafting process; they had invited representatives of the CFA to SRIB meetings, but invitees had shown up only once or twice. The people from the Calais community and Farm Three did not seem interested in participating, presumably because their location at the head-end of the canal allowed them to use water first and freely. Reportedly, they were also unwilling, or unable, to pay levies to the SRIB as had been requested during meetings of the board.

\section{Redistribution of farms under the SLAG scheme: 1997-1999}

While some White farmers readily sold their property under SLAG schemes, most were strongly opposed to land redistribution projects. In 1997, the FATO formed a three-member "land affairs committee", which raised, in a period of three years, no less than 30 objections and proposals to stop redistribution of Farm Three and Farm X. Farmers were particularly concerned about the future of Farm Three because they feared that the transfer of this farm, located in the upper catchment, to a large number of Black farmers would seriously endanger their water security. They framed this concern in general environmental or economic sustainability terms, arguing that the region should be considered in its entirety - with a "helicopter view" - to safeguard a future for commercial farming. ${ }^{18}$

The process of transfer was another source of anxiety and frustration for the commercial farmers. This process came to be known in South Africa as the "rent-a-crowd" syndrome (May and Roberts 2000, cited in Hall 2010). Real estate agents, sometimes in collaboration with farmers, rather arbitrarily collected signatures from people to compile lists of "beneficiaries" supposedly interested in pursuing collective production on former commercial farms. With these lists, commercial farmers were ready to sell their property. With a maximum number of beneficiaries, making use of SLAG subsidies of ZAR15,000 per beneficiary, the real estate agents could offer prices that were higher than the market rate. Initially, the government was reluctant to interfere in this process because of their adherence to the "willing seller, willing buyer" principle. ${ }^{19}$

Letters by the FATO sent to various government departments complained about the "rent-a-crowd" dealings, stating that Farm Three had been sold for seven times its original value and Farm X for more than double the market price. ${ }^{20}$ In October 1998, an ANC official even brought the case of Farm Three to the personal attention of the minister of agriculture and land affairs. In recognition of the seriousness of the situation, the minister himself paid a visit to the area. On the occasion of his visit, he publicly stated that the transfer of the farm had been a policy mistake that was not to be repeated in South Africa. ${ }^{21}$

Encouraged by this, FATO farmers wrote him a letter requesting a national moratorium on SLAG schemes. This moratorium was announced in July 1999 (Hall 2010). However, commercial farmers felt this came too late, because land had already been transferred to large groups of beneficiaries, resulting in loss of control over the allocation and use of water resources on and around those properties. It is not clear whether or not their fears were justified because in 2006 SLAG land transfers had not yet resulted in drastic changes in water use patterns, partly because Black beneficiaries did not have the means to access and use water for farming or for other purposes. ${ }^{22}$

\section{Transfer of farms for the restitution of land rights: 2000-2005}

Land transfers in the area under SLAG subsidies in 1997 and 1998 had caught most farmers off guard. Redistribution of farms had happened with individual farmers acting on their 
own account, while those who stayed behind had to face the consequences. In many ways, restitution claims perturbed the remaining White farmers' community, but they knew that they could not stop land transfers, and in 2001 they also came to know that they were not allowed to remain as share or lease-holders. ${ }^{23}$ Like the SLAG, the restitution of land rights provoked farmers' fears of losing control over water resources. Having learned from the SLAG experience, farmers knew they had to remain vigilant when land transfers started to happen under the "restitution of land rights" scheme.

In 2002, farmers learnt that one billion ZAR (approximately 89 million USD) was available for compensation for the restitution of land. ${ }^{24}$ This created an attractive exit strategy. Furthermore, it was understood that farms were meant to remain undivided productive properties, which meant that farmers who decided to stay did not have any future prospects of large settlements on nearby properties. This meant that they would not have to negotiate with large groups of Black users about water resources. The farmers realized that their chances of successful negotiations depended on their ability to act as a group. They set out to talk with the government and claimants about an overarching settlement for the whole area, rather than negotiating about separate properties. They had come to realize that their only possibility was to simultaneously secure compensation for those who left and secure water control for those who stayed. In contrast, for claimants it was more favourable to discuss each land claim as an isolated procedural affair, because this offered them the best chances to secure a particular property (and the related water resources). When a land claim was dealt with separately, claimants only had to talk with the government, rather than also having to negotiate with other claimants and with commercial farmers.

In particular, the water security of the remaining commercial farmers importantly depended on their ability to control the land in the upper catchment. However, this land was controlled by the state, and, in principle, regardless of its "nature reserve" status, could be transferred to claimants without consultation with White farmers. White farmers therefore invested considerable energy in ensuring that this area became part of the deal by arguing for a joint treatment of land right restitution claims. This is why the negotiations between Limpopo's Land Claims Commission and the FATO's chairman focused in particular on the state-property Farm Zero in the LNR. Farm Zero covers roughly 25\% of the upper catchment of the Selati River, including the Macheke Springs. On 26 April 2003, Farm Zero had already been listed in the Government Gazette, a procedural step for transfer. Recognizing the urgency of the situation, in June 2003, the farmers succeeded in arranging a meeting between the government, claimants and farmers at the Ofcolaco Club to discuss the upcoming transfer of Farm Zero. The minutes mention that claimants were "committed to pursuing their claim as it was proclaimed in the government gazette", indicating that they wished to pursue their claim for Farm Zero as a separate procedural issue.

However, these same minutes also note that "the publication of the claim on [Farm Zero] was noted to be outside the global view of the whole Trichartsdal/Ofcolaco area which has been discussed at length with the Limpopo Province Land Claims Commission". This extract shows how successful the strategy of the commercial farmers was in including Farm Zero in an overarching settlement. Before the meeting, the Regional Land Claims Commission had apparently decided that Farm Zero could no longer be transferred as a separate property. This meant that the notice in the Government Gazette was invalidated. The minutes also testify that land negotiations around Farm Zero were in fact about safeguarding water resources, at least for the commercial farmers. ${ }^{25}$ For instance, the Chairman of the FATO made his plea by saying that "without water the entire Trichardtsdal/Ofcolaco area will fail as a farming area". He continued by putting forward conservation arguments to justify the exclusion of Farm Zero from any future land transfers. He insisted that the 
Trichardstdal-Ofcolaco area must be considered as a whole, and claimed that the area was already declared a conservation area as far back as $1881 .^{26}$

An additional strategy of the farmers to remain in control of water resources, over and above their opposition to the transfer of Farm Zero, was to claim authority over the full catchment area of the Selati River under a new WUA. Paradoxically, in the meeting, farmers explicitly mentioned the National Water Act (1998), designed in part to redress past inequities, to support their claim. The strategic importance of Farm Zero as a water reservoir was such that the farmers even offered land elsewhere in return for excluding Farm Zero and other land in the Lekgalameetse area from land transfers. They also proposed mentorship at the meeting to train and assist new owners. ${ }^{27}$ Although these proposals were rejected, their overall lobbying was successful. The minutes of this meeting recorded that recommendations were made by the government to include the Macheke Springs in the LNR, and to renegotiate with the claimants about Farm Zero. Furthermore, the 13 Trichardsdal farms which were transferred under the Sekororo claim did not include Farm Zero in the end. One of the farmers who sold his property as part of the settlement continued farming as one of the strategic partners of the MCPA in 2006, now with secure land rights and secure water sources.

\section{Conclusions}

By documenting the strategies of White commercial farmers in dealing with government interventions to redistribute land and reform water use, this article has shown that land and water reforms are deeply interconnected. To safeguard their continued access to and control over water, farmers strategically made use of new water policies, and simultaneously used land redistribution negotiations. Overall, these findings illustrate that land transfers (and the simultaneous transfer of the water resources and technology connected to that land) offered opportunities for farmers and claimants to secure water. For instance, Farm Three and three farms of the MCPA remained included in the new irrigation schedule of the SRIB, revealing that some sort of redistribution of water resources had taken place, from White commercial farmers to Black claimants. This happened through land transfers, and not through policy attempts as articulated in the South African water law to transform irrigation boards into more "inclusive" WUAs.

Key to the strategies of the commercial farmers was that they used the terminology of the new policies (paradoxically designed to redress past inequities) and the language of nature conservation and ecological stewardship to legitimize their claims for land and water. This is similar to what Fortmann (1995) observed among commercial farmers in Zimbabwe. Farmers in the research area thus successfully made use of "environmental" arguments such as "protection" of the "catchment" area of the Selati River to sustain the status quo, while it had been their own intensive irrigated farming practices that had caused progressive overexploitation and scarcity of water resources in the first place. Protecting a fragile catchment area from development is desirable from an ecological perspective, but, in this case, the implementation of nature conservation and environmental protection goals also worked against the policy goal of redressing inequities.

These findings have important policy implications. For one, new water laws and policies fail to produce transformative impacts (through registration of water use and changing irrigation boards into WUAs) when leaving existing water use formally unchallenged (through "existing lawful uses"). Second, water use may be secured and/or challenged implicitly through land reforms. The realization that water claims may take the form of land and conservation area claims underscores the importance of greater awareness of the 
linkages between nature, land and water resources in agrarian reform policies. A first step here would be to acknowledge that negotiations on water resources and conservation area claims, and on what is considered fair based on what grounds, are a prerequisite for land transfers, rather than issues that can be dealt with separately from (after or parallel to) land reforms. Hence, land transfers are likely to become less cumbersome, and land and water reforms may become more transformative, when negotiations over water resources and the status of nature conservation areas in relation to equity perspectives are thoughtfully planned for as part of land reforms.

\section{Notes}

1. The apartheid system classified people into racial groups called "black", "white", "Indian" and "coloured". In the research area, historically disadvantaged individuals and commercial farmers (still) used the terms "black" and "white" during interviews when explaining their perspective on land and water reforms. In respect of their views, and to differentiate between the perspectives of "black" and "white" commercial farmers in the area, the terms "Black" and "White" are used in this text as perceived categories of people. The intention is not to use the terms in a derogatory manner.

2. The sample constituted about $90 \%$ of the commercial farmers in the Trichardtsdal-Ofcolaco area and approximately $50 \%$ of all the farmers in the adjacent Leydsdorp area. There were hardly any female respondents during field research. There were conversations with wives and daughters of the commercial farmers, but they pointed to their husbands for discussing farming practices and matters of land and water reform. Some women expressed that commercial farming entails a lifestyle in the White farmers' community that is associated more positively with ideals and stereotypes of men than of women. They explained that men, more than women, nurture the motivation to pursue commercial farming operations.

3. In total, 9 out of 24 commercial farmers also kept livestock, mainly cattle for beef production, dairy cows and chickens.

4. Agri South Africa (AgriSA), originally established in 1904 as the South African Agricultural Union, is a federal agricultural trade organization in South Africa. AgriSA promotes, on behalf of its members, the development, profitability, stability and sustainability of commercial agriculture in South Africa by means of its involvement and input on national and international policy level (see http://www.agrisa.co.za).

5. Information obtained from an old brochure of the Ofcolaco Farmers' Association (dated approximately 1930).

6. Information obtained from a letter of the FATO sent to the Minister of Environment and Water Affairs (dated 8 March 1990). Copy obtainable from the lead author.

7. Information obtained from a press release by the Minister of Constitutional Development and Planning (dated 12 August 1985) and an announcement by the state president (dated 14 August 1985) in connection with the consolidation decisions with respect to the national state of Lebowa, as well as from a letter of the Agricultural Union of Letaba District to the local farmers' association about the "Trichardtsdal consolidation" (dated 20 August 1987).

8. Correspondingly, a database held by the DWAF showed a steep increase in borehole installations in this period (1987-1992) (Chapman 2006).

9. Some farms in the vicinity of the research area were redistributed under the Land Redistribution for Agricultural Development (LRAD) programme launched in 2001 (see Hall 2010 for background on the LRAD).

10. The names of the properties have been made anonymous. The farms with a number in the name (Farms Zero through Eleven) fall within or on the border of the area under the jurisdiction of the SRIB. The farm with a letter in the name (Farm X) falls outside this area.

11. In strategic partnership schemes, $50 \%$ of the shares are held by an operation company (investors and often White farmers/managers), $48 \%$ by a communal property association (usually Black beneficiaries), and $2 \%$ by a labourers' trust (for those who work on the farms).

12. The National Water Act of 1998 describes four categories of water use authorizations: (1) Schedule 1 for small volumes of water for household use; (2) General Authorizations for larger volumes of water for any specific type of water use and/or any category of user; 
(3) Existing Lawful Use (see main text); and (4) Licensed Water Use for water use authorized in terms of a license issued under the National Water Act. All categories of water use, except under Schedule One, are subject to water use registration, and should be registered in the Water Authorisation Registration Management System (WARMS). Water use by the commercial farmers in the research area has been subject to water use registration (see main text), which implies that it is considered to fall under the definition of Existing Lawful Use, because the other categories are not applicable for their situation.

13. Minutes of a meeting (dated 31 July 1990) between the then Department of Water Affairs and the farmers reveal that farmers wanted to register water use even then.

14. See explanation in Note 12.

15. What was the DWAF prior to 2009 is now the Department of Water Affairs (DWA), falling under the Ministry of Water and Environmental Affairs.

16. A letter of the FATO to the government (dated 11 June 1987) reveals that farmers had already approached the state in 1987, requesting that it build a dam in the LNR for better water supply. These plans were taken up again in a letter to the DWAF (dated 21 September 2005) after an invitation from the DWAF for "water storage and usage proposals".

17. Farmers in the adjacent Leydsdorp area were not consulted in the process, although their farms were located in the (lower) catchment of the Selati River. The boundaries of the new WUA jurisdiction area were not extended downstream, hence the name "Upper Selati WUA" rather than "Selati WUA". Apparently, the concerns of SRIB farmers to secure water resources outweighed opportunities to strengthen a new WUA with more White farmers as members.

18. Information obtained from various letters and proposals from the FATO in 1998 (among others, dated 26 March 1998 and 7 September 1998), concerning Farm Three and the CFA, and Farm $\mathrm{X}$ and Madiba Trust.

19. Information obtained from a letter of the Department of Agriculture, Land and Environment (dated 21 April 1998), sent to the FATO in response to their objections about "rent-a-crowd" practices.

20. Information obtained from a letter of the FATO (dated 9 February 1998), sent to the Department of Agriculture, Land and Environment, and other letters sent in 1998 to various departments.

21. Information obtained from an untraceble local newspaper article (dated 4 October 1998), "Landbou was te haastig" (Agriculture was too hasty). Copy obtainable from the lead author.

22. The same local newspaper article (see Note 21) mentions that irrigation equipment was destroyed in a bush fire shortly after transfer of Farm Three and that no new equipment was provided by the government.

23. Information obtained from the minutes of the FATO (dated 15 March 2001).

24. Information obtained from the minutes of the FATO (dated 22 March 2002). We assume that the amount of one billion ZAR was available in the equivalent of USD, approximately 89 million USD. The USD equivalent was calculated using the exchange rate of 22 March 2002 (11.27 ZAR per unit USD).

25. Minutes of the meetings reveal that claimants, among others, were committed to pursuing their claims for Farm Zero because the property contained grave sites and other ritual places sacred to the claimants' communities.

26. The minutes of this meeting (dated 4 June 2003) reveal that the first title deeds in the area date from 1899, and that a first mapping of the area took place in 1904. Without mapping and title deeds, it is impossible to precisely designate the Lekgalameetse as a "nature reserve". Other documents show that the Lekgalameetse area obtained a conservation status in the mid-1980s (see Note 7).

27. The minutes of this meeting (dated 4 June 2003) reveal that the farmers offered nine productive farms in the Trichartsdal/Ofcolaco area, together with a business plan for present owners to remain and assist new owners.

\section{References}

ANC, 1994. The reconstruction and development programme: a policy framework. Johannesburg: African National Congress.

Anderson, A.J., et al., 2008. Integrated monitoring of water allocation reform in South Africa. Water SA, 34 (6), 731-737. 
Anseeuw, W., and Alden, C., eds., 2010. The struggle over land in Africa: conflicts, politics and change. Cape Town, South Africa: HSRC Press.

Boelens, R., and Zwarteveen, M., 2005. Prices and politics in Andean water reforms. Development and Change, 36 (4), 735-758.

Brown, J., 2011. Assuming too much? Participatory water resource governance in South Africa. Geographical Journal, 177 (2), 171-185.

Chapman, A., 2006. Hydrology and land-use in the Ga-Selati Catchment. Council for Scientific and Industrial Research, Pretoria, and International Institute for Environment and Development, London.

Chikozho, C., 2008. Globalizing integrated water resources management: a complicated option in Southern Africa. Water Resources Management, 22, 1241-1257.

Dippenaar, S., Moilwa, N., Olorunju, S., and Visser, A.E., 2005. An analysis of the livelihoods of communities of the upper Selati Catchmnent, South Africa. Pretoria, South Africa: Center for Scientific and Industrial Research (CSIR) and London, UK: International Institute for Environment and Development.

DWAF, 1999. Guide on the transformation of irrigation boards and certain other boards into water user associations. Pretoria, South Africa: Department of Water Affairs and Forestry.

DWAF, 2005. A draft position paper for water allocation reform in South Africa: towards a framework for water allocation planning. Discussion document. Pretoria, South Africa: Water Allocations Directorate, Department of Water Affairs and Forestry.

Fortmann, L., 1995. Talking claims: discursive strategies in contesting property. World Development, $23(6), 1053-1063$.

Goldin, J.A., 2010. Water policy in South Africa: trust and knowledge as obstacles to reform. Review of Radical Political Economics, 42 (2), 195-212.

Government Gazette, 1964. Notice no. 338 of 1964, 11 December 1964.

Hall, R., 2010. Two cycles of land policy in South Africa: tracing the contours. In: W. Anseeuw and C. Alden, eds. The struggle over land in Africa: conflicts, politics and change. Cape Town, South Africa: HSRC Press, 175-192.

Hann, C.M., 1998. Introduction: the embeddedness of property. In: C.M. Hann, ed. Property relations: renewing the anthropological tradition. Cambridge: Cambridge University Press, $1-53$.

Herrfahrdt-Pähle, E., 2010. South African water governance between administrative and hydrological boundaries. Climate and Development, 2, 111-127.

Kemerink, J.S., Ahlers, R., and van der Zaag, P., 2011. Contested water rights in post-apartheid South Africa: the struggle for water at catchment level. Water SA, 37 (4), 585-594.

Kirsten, J.F., Perret, S., and van Zyl, J., 2000. Land reform and the new water management context in South Africa: principles, progress and issues. Seminar of the Natural Resources Management Cluster and Land Policy Thematic Group, the World Bank, Washington DC, 27 September 2000.

Krippner, G., 2001. The elusive market: embeddedness and the paradigm of economic sociology. Theory and Society, 30, 775-810.

Liebrand, J., 2009. The deep waters of land reforms: a case study on land and water reforms in the Olifants basin, South Africa. Köln: Lambert Academics.

McCay, B.J., and Jentoft, S., 1998. Market or community failure? Critical perspectives on common property research. Human Organization, 57 (1), 21-29.

Meinzen-Dick, R., and Nkonya, L., 2007. Understanding legal pluralism in water and land rights: lessons from Africa and Asia. In: B. van Koppen, M. Giodiano, and J. Butterwort, eds. Community-based water law and water resource management reform in developing countries. Oxfordshire: CAB International, 12-27.

Merrey, D.J., Lévite, H., and Van Koppen, B., 2009. Are good intentions leading to good outcomes? Continuities in social, economic and hydro-political trajectories in the Olifants River Basin, South Africa. In: F. Molle and P. Wester, eds. River basin trajectories: societies, environments and development. Comprehensive assessment of water management in agriculture, No. 8. Wallingford, UK: CAB International and International Water Management Institute, pp. 47-74.

Peluso, N., and Lund, C., 2011. New frontiers of land control: introduction. Journal of Peasant Studies, 38 (4), 667-681.

Polanyi, K., 1944. The great transformation. Boston: Beacon Press.

Ribot, J., and Peluso, N., 2003. A theory of access. Rural Sociology, 68 (2), 153-181. 
Roth, D., Boelens, R., and Zwarteveen, M., eds., 2005. Liquid relations: contested water rights and legal complexity. New Brunswick: Rutgers University Press.

RSA (Republic of South Africa), 1994. Restitution of Land Rights Act. Act no. 22 of 1994. Cape Town: Office of the President.

RSA (Republic of South Africa), 1998. National Water Act. Act no. 36 of 1998. Cape Town: Office of the President.

Sikor, T., and Lund, C., 2009. Access and property: a question of power and authority. Development and Change, 40 (1), 1-40.

Turton, A.R., Meissner, R., Mampane, P.M. and Seremo. O., 2004. A hydropolitical history of South Africa's international river basins. Water Research Commission report No. 1220/1/04, African Water Issues Research Unit (AWIRU), University of Pretoria.

Van Koppen, B., and Jha, N., 2005. Redressing racial inequities through water law in South Africa: interaction and contest among legal frameworks. In: D. Roth, R. Boelens, and M. Zwarteveen, eds. Liquid relations: contested water rights and legal complexity. New Brunswick: Rutgers University Press, 195-214.

von Benda-Beckmann, F., and Spiertz, H.L.J., 1996. Water rights and policy. In: H.L.J. Spiertz and M.G. Wiber, eds. The role of law in natural resource management. The Hague: VUGA, 77-99.

von Benda-Beckmann, F., von Benda-Beckmann, K., and Wiber, M.G., 2006. The properties of property. In: F. von Benda-Beckmann, K. von Benda-Beckmann, and M.G. Wiber, eds. Changing properties of property. New York: Berghahn Books, 1-39.

Waalewijn, P., Wester, P., and van Straaten, K., 2005. Transforming river basin management in South Africa: lessons from the Lower Komati River. Water International, 30 (2), 184-196.

World Bank, 2003. Water resources sector strategy: strategic directions for World Bank engagement. Washington, DC: World Bank.

Zwarteveen, M., 1997. Water: from basic need to commodity. A discussion on gender and water rights. World Development, 25 (8), 1335-1350. 